\title{
Clustering Technique to Improve Rural Malaysian Primary School Pupils’ Writing Skill
}

\author{
Sharon Lawai, Azlina Abdul Aziz
}

\begin{abstract}
For pupils in rural areas, English has been one of the most challenging and difficult subjects to learn. Environment, outreach and resources to English materials are among the reasons they are lacking of exposure to the language. It is no wonder the majority of rural school pupils faced hiccups when it comes to written composition. This paper investigates on the use of clustering technique in improving rural primary pupils' writing skill by employing action research. The objectives of this study are (1) to find out whether clustering technique can help pupils to improve on their writing skill, (2) to look into pupils' perception on the use of clustering technique in writing. Based on the results accumulated, it was found that clustering was effective in improving the pupils' writing and they also perceived positive attitude towards the technique during their writing process.
\end{abstract}

Index Terms - clustering, rural primary, written composition

\section{INTRODUCTION}

Writing is one of the most fundamental skills to master in learning a language. It is also one of the most difficult skills to learn as it requires several skills and conventions to be mastered (Nik et. al, 2010). Writing is particularly difficult for second language learners as they expected to master a variety of linguistic, cognitive and sociocultural competencies in the target language in order to be able to perform in writing (Barkaoui, 2007). According to Richard and Renandya (2002), writing requires one to think critically in terms of word production, sentences and paragraphs at the same time. To produce a good written composition, there are numerous aspects to consider. Writing is not just an activity of putting down some words or sentences into the written language, but also the activity of arranging words into well-organised writing. It involves critical thinking that requires the pupils to be able to express their ideas and produce it into words, sentences and paragraphs. To be able to master this skill however, it is vital for pupils to have background knowledge of the target language, vocabulary, spelling and grammar in order to be able to produce a meaningful writing product.

Before the writing activity, pupils must brainstorm ideas for the content. They also have to be aware of the grammatical items of a language when producing sentences such as subject-verb-agreement, appropriate tenses, singular-plural and so on. Lack of vocabulary in the target language may hinder their creativity to properly tell a story.

In 2017, despite achieving a significant increase in English performance for the primary school public examination as compared to the former year, English is still considered as one of the most difficult subjects to pass particularly for rural primary school pupils whereby the exposure to the English language is scarce. Based on reports written by Nooreiny et al. (2003) and Talif \& Edwin (1990), the proficiency level in English language in rural schools is much lower as compared to the level in urban schools although students went through the same curriculum. In a study conducted by Samuel and Zaitun Bakar (2008), in most cases of writing, it was found that Malaysian rural learners still fail to produce even a short paragraph of comprehensible writing.

For these rural pupils, English is considered difficult to learn or acquire due to several factors such as the influence of mother tongue, limited resources to English materials and geographically remote area. Monolingual environment is also another factor that hinders these pupils to practice the language. Unlike urban pupils, these rural learners have very limited platform to practice the language in authentic situation. They spend most of the time around their monolingual community and only exposed to the language during formal school period. Consequently, they have lack of exposure to the language and limited vocabulary. Limited vocabulary eventually impedes their ability to convey ideas in written production.

After years of teaching in one of the rural schools in Sarawak, the researcher found that these pupils usually faced hitches during the pre-writing stage whereby they need to brainstorm ideas for their writing. Due to their poor command in English, they were only able to write an essay with merely a few sentences and thus failed to properly deliver what they wished to write about. Firmansyah (2015) in his study also revealed that some of the major problems faced by students in writing are their lack of ability to generate ideas, difficulty in producing paragraphs and struggle to select words due to lack of vocabulary. In order to overcome this problem, a technique is planned to assist the pupils in their writing. There are a number of techniques that can be used to improve or teach pupils in writing a descriptive text. In this case, an alternative technique is applied namely "clustering technique".

The objectives of this research are (1) to find out whether clustering technique can help pupils to improve their writing skill, (2) to look into pupils' perception in using clustering technique in writing. This research also aimed to answer the following questions (1) how can the use of clustering technique improve rural pupils' writing skill? (2) how do the pupils perceive clustering technique in improving their writing? 


\section{LITERATURE REVIEW}

\section{A. Writing Process}

Writing involves several processes. Harmer (2004) stated that writers generally go through four basic writing processes namely planning, drafting, editing and final draft. These processes are recursive and writers are allowed to jump back and forth from one stage to another as they write. Pupils generate ideas during the pre-writing stage. At this stage, pupils may utilise any writing strategies such as listing, clustering or mapping to help generate and link ideas for their writing. They would then proceed drafting their composition before moving on to editing. Pupils may go back and forth between these stages of writing until they are pleased with their final product.

\section{B. Teaching Writing}

Ability to write is a fundamental skill for learners of second language much like their ability to write in the first language. Writing in second language is especially difficult when one does not have sufficient vocabulary in the language. Language teachers should place extra attention when teaching writing to second language learners. Teaching ESL learners to acquire writing skills is not an easy task (Fatt, 2007). Level 2 primary school pupils are expected to be able to express their ideas in writing and be an independent writer for as long as they have sufficient knowledge in the target language. Writing is even more difficult in the rural areas as social interaction in English with teachers or peers are almost non-existent (Chitravelu et. al, 2005). Based on observation, these rural pupils are yet to achieve even the lowest band of A1 in their writing based on the Common European Framework of Reference for Languages (CEFR) benchmark. Language teachers play a crucial role in directing the pupils on what to write rather than how to construct a written composition. Flower and Hayes (2008) stated that writers compose or organize a set of distinctive thinking processes during the act of writing. Therefore, it is fundamental for teachers to provide ample amount of time for the pupils to use their thinking skills to generate ideas for composition. Teachers must encourage them to plan their writing by brainstorming during the pre-writing stage to get them accustomed. This stage provides pupils the tools and foundation for successful writing (Cunningham \& Cunningham, 2010). Teachers also need to support pupils through modelling, provide clear and explicit learning goals and offer meaningful writing practices as well as plan a structured writing activity. Teachers could also use scaffolding method as another alternative in teaching writing. This method will allow language teachers to assist pupils in writing and slowly encourage them to be more independent (Palincsar, 1998).

\section{The Importance of Improving Writing}

Writing is an essential component of literacy. It is also one of the four skills (listening, speaking, reading and writing) integrated in the Malaysian Primary School Curriculum Standard (KSSR) for English language learning. Writing began from an early age in a child's education. Malaysian Ministry of Education (MOE) recognised the importance of writing for students' achievement. Early writing practices support the development of pupils' critical thinking and problem solving skills (Polisena, 2017). Therefore, it is beneficial for young learners to acquire writing skill from an early age. Over the years, MOE has conducted numerous programs to curb literacy problems amongst pupils. One of the programs conducted in primary school level was LINUS. The objective of this program was to identify students with literacy problem in two major areas which were reading and writing. Based on the LINUS screening tests, teachers would be able to identify the students' Achilles heels and thus be able to find alternatives to assist these students to perform in their academic achievement. This alternative by MOE is essential since writing is interrelated with other skills (Saed \& Al-Omari, 2014). Improving writing skills will help to enhance other skill area such as listening, speaking and reading (Saed \& Al-Omari, 2014). Ahangari and Behzady (2011) also agrees that writing is one of the best method to know the students' learning progress. In addition, current academic and professional fields demand competent writers. Opportunity for further education and employment may be restricted should the students fail to acquire good writing skill.

\section{Clustering}

A good writing is generated from a process of writing. Pre-writing is the first step of the writing process. This crucial step is where a writer organises ideas and structures contents for writing. Clustering can be employed in this stage. Clustering is another way to manage and narrow down topic for short essay from expansive subject (Buscemi, 2002). According to Wyrick (2011), clustering helps learners to collect important details on given topics and emphasise on things that they wish to write or describe in their writing. Clustering can be practised by drawing visual charts, maps, webs or diagrams (Langan, 2005). It is the production of visual map of ideas (Smalley et. al, 2012). This technique is beneficial for visual learners as it is useful for any types of writing.

Clustering is a prewriting activity that helps the pupils to prepare their drafts for writing. They can utilise visual charts to generate ideas for writing by clustering information or details through words or phrases that might be useful in their essay. Clustering words or phrases offers a starting point for writers to visualise and understand their world through different perspective (Folit, 2009). By clustering information, it helps learners to associate ideas or link information for their writing. This technique also provides a platform for learners to remember their writing ideas or details and thus support them to develop paragraphs for more coherent writing.

A research conducted by Alawi (2011) to study the effect on clustering technique in improving students' descriptive text showed that students has improved their writing ability when composing descriptive texts. The result was evident based on the data collected. He also discovered that the teacher showed positive responses towards clustering technique and this technique would act as an alternative in teaching writing for the students.

\section{Methodology}

\section{A. Research Design}

This study employed action research design. Action research design was employed as it allows limited number of research participants and the researcher sought to improve her own 
practices (McNiff, 2002). The model of action research used in this study was based on a model developed by Kemmis and McTaggart (1988). There are four steps involved in this model.

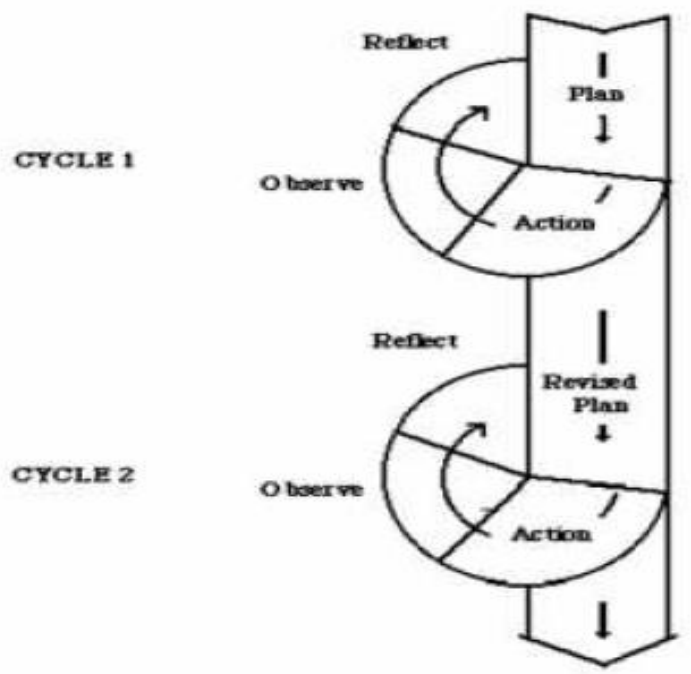

Figure 1. Kemmis \& McTaggart action research model

Before the implementation of action, the researcher conducted a pre-test on the participants. After obtaining and analysing the pre-test result, these participants were introduced to clustering technique. In order to gain significant improvement, a few cycles were conducted. During the final post-test, the participants were given the same topic as the pre-test to validate their writing progress after the being introduced to the technique.

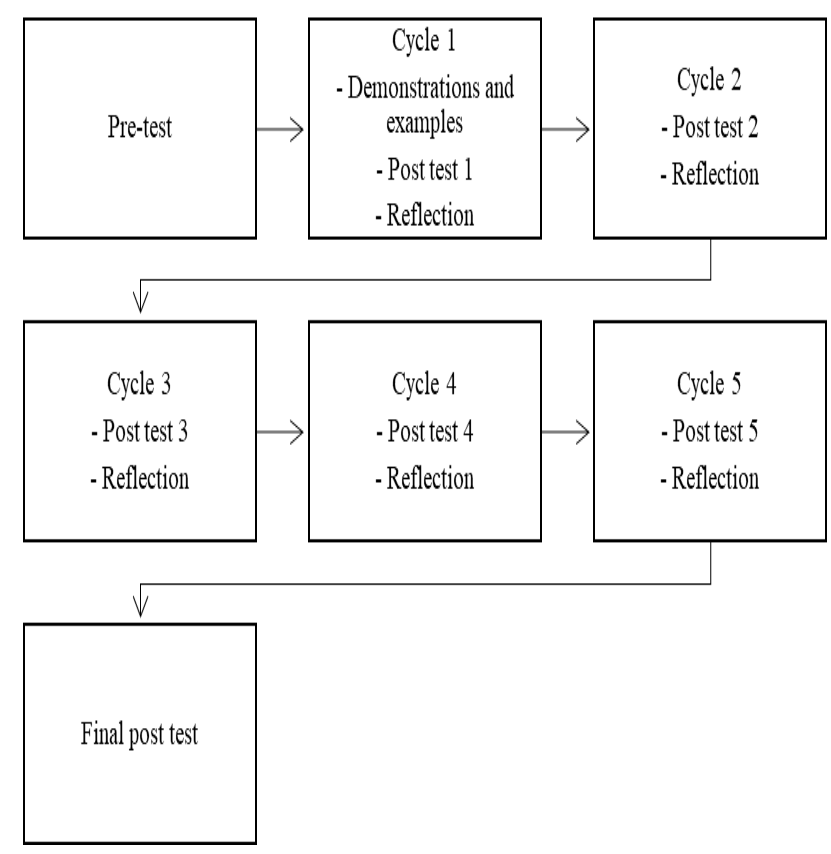

Figure 2. Research steps and procedure

\section{B. Research Setting and Participants}

This study took place in one of the rural school in Baram, Sarawak where the researcher is currently in service. The school is about 6-7 hours of journey from Miri city and only accessible by $4 \times 4$-wheels vehicles and another 5-minute boat ride. When this study was conducted, there were only a total of 15 pupils in the school. Therefore, only 5 participants were involved in this research due to the limited number of pupils in the school; 2 pupils from Primary 4 and 3 pupils from Primary 5 . The participants consist of 3 boys and 2 girls. They were selected through purposive sampling. They were selected due to their low proficiency level in English as well as in their writing competency.

\section{Research Instruments}

Research instruments are vital for the analysis and evaluation of data collected. The instruments used in this study were:

i. Field notes : Participants were observed throughout the research process. Their behaviour and attitudes during the process were taken note of.

ii. Interviews : Semi-structured interview was done to obtain the participants' opinions and feedbacks on the activities during the research.

iii. Documentation : Learning materials or post-tests were used to assess the participants' learning progress. To understand the participants' ability in brainstorming ideas for their writing, a pre-test was conducted. Final post-test was taken to measure significant improvement in the participants' writing after implementing the technique. Their clustering maps and writings were assessed in every post-test given.

\section{DATA ANALYSIS}

To evaluate the participants' writing, they were given tests to observe their progress before and after the implementation of this technique. Both pre-test and final post-test scores were compared after the intervention. Document analysis was performed on the participants' writing. Standard Curriculum for Primary School (KSSR) marking criteria for writing was used to assess their writing. These criteria are used in the UPSR examination for Paper 2 Section C. The overall marks for the section is 25 marks. Therefore, this was the mark used to measure the participants' writing ability in this study. The scoring guide is shown Table 1.

Table 1. KSSR marking scheme for Section C

\begin{tabular}{|c|l|}
\hline $\begin{array}{c}\text { Scores/ } \\
\text { Bands }\end{array}$ & \multicolumn{1}{c|}{ Descriptors } \\
\hline $\begin{array}{c}\text { Distinguished } \\
(22-25)\end{array}$ & • Accurate use of language with varied and \\
& - - Wephisticated sentence structure. \\
& - Well-crafted paragraphs \\
& - Entirely correct punctuation \\
& - Vocabulary creates strong image \\
& - Accurate spelling \\
\hline Excellent & - Generally correct use of language \\
$(16-21)$ & - Almost well-planned ideas \\
& - Almost well-crafted paragraphs \\
& - Almost always correct punctuation \\
& - Almost effectively use of vocabulary \\
& - Mostly accurate spelling \\
\hline Good & - Sufficiently accurate use of language \\
$(10-15)$ & - Generally well-planned ideas \\
\hline
\end{tabular}




\begin{tabular}{|c|l|}
\hline & - Generally well-crafted paragraphs \\
& - Generally accurate punctuation \\
& - Accurate, precise use of vocabulary \\
& - Generally accurate spelling \\
\hline $\begin{array}{c}\text { Satisfactory } \\
(5-9)\end{array}$ & - Meaning is clear with frequent errors in \\
& - simple sentences \\
& - Attempts made on some ideas \\
& - Some accurate punctuation \\
& - Correct spelling on high frequency \\
\hline Weak & vocabulary \\
$(0-4)$ & - Poor paragraphing \\
& - Correct spelling of sight words \\
& - Chunking of ideas \\
\hline
\end{tabular}

Their attitudes towards the activities in every cycle was observed and recorded in field notes. These observations were done to find out whether it corresponds with the participants' opinions on the technique. As for the participants' perceptions, an oral interview was conducted to obtain their opinions on clustering technique. Both their responses and observations were analysed using thematic analysis in order to find common results.

\section{FINDINGS}

Research question 1: How can the use of clustering technique improve rural pupils' writing skill?

After analysing the tests scores, it was found that the participants were able to applied clustering technique to generate more ideas for their writing. They were able to provide more details in their cluster map. Thus, their written compositions were more elaborate compared to before the intervention.

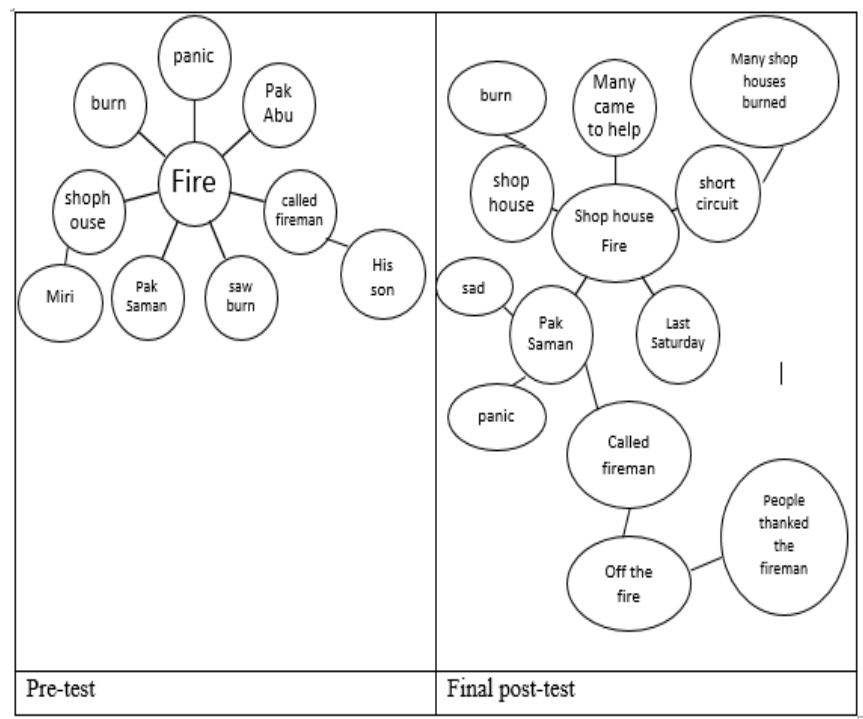

Figure 3. Sample from the participants' idea cluster

The results for pre-test and post-tests for each cycle were tabulated as below.
Table 2. Pre-test and post-tests scores

\begin{tabular}{|c|c|c|c|c|c|c|c|}
\hline Participants & Pre & $\mathbf{1}$ & $\mathbf{2}$ & $\mathbf{3}$ & $\mathbf{4}$ & $\mathbf{5}$ & Final \\
\hline A & 3 & 3 & 5 & 7 & 7 & 8 & 10 \\
\hline B & 4 & 5 & 5 & 7 & 8 & 10 & 12 \\
\hline C & 6 & 7 & 8 & 10 & 13 & 14 & 16 \\
\hline D & 8 & 9 & 11 & 13 & 14 & 16 & 18 \\
\hline E & 9 & 10 & 12 & 14 & 16 & 18 & 20 \\
\hline Total & 30 & 34 & 41 & 51 & 58 & 66 & 76 \\
\hline Mean & 6.0 & 6.8 & 8.2 & 10.2 & 11.6 & 13.2 & 15.2 \\
\hline
\end{tabular}

The results of pre-test and final post-test were compared and tabulated as follow:

Table 3. Scores gained by the participants based on their pre-test and post-test

\begin{tabular}{|c|c|c|c|}
\hline Participant & Pre-test & $\begin{array}{c}\text { Final post } \\
\text { test }\end{array}$ & $\begin{array}{c}\text { Gained } \\
\text { Scores }\end{array}$ \\
\hline A & 3 & 10 & 7 \\
\hline B & 4 & 12 & 8 \\
\hline C & 6 & 16 & 10 \\
\hline D & 8 & 18 & 10 \\
\hline E & 9 & 20 & 11 \\
\hline Total & 30 & 76 & 46 \\
\hline Mean & 6.0 & 15.2 & 9.2 \\
\hline
\end{tabular}

To calculate the percentage between these two scores, this formula was applied:

$$
\begin{aligned}
& P=\frac{\text { Post test }- \text { Pre-test }}{\text { Total marks }} \times 100 \% \\
= & \frac{15.2-6.0}{25} \times 100 \% \\
= & 36.8 \%
\end{aligned}
$$

There was a significant improvement in writing score based on analysis conducted on the pre-test and final post-test scores. A formula was applied to test the percentage of score improvement between the two tests. The result showed that the participants' writing ability has improved by $36.8 \%$ with the use of clustering technique. From this result obtained, it can be concluded that the participants had improved their writing skill with the use of clustering technique after a few cycles.

Research question 2 : How do the pupils perceive clustering technique in improving their writing?

From the observations, it was found that the participants gradually showed positive attitudes towards the use of clustering technique for their writing. Their cluster maps had more details and elaborate. Based on the analysis of their interview, it can be inferred that the participants' had positive perceptions towards the use of clustering technique for their writing. They claimed that writing is easier as clustering technique managed to assist them to generate more ideas for their compositions. Overall, their responses towards the technique were positive and well-accepted to be applied in their writing practices. Some of their interviews were as follow:

Question: What do you think about writing essays in English? 
Participants' Responses:
A: Difficult
B: Hard
C: Difficult but can write a bit
D: Hard
E: Difficult, so many things to remember

Question: Do you have any writing strategies to help you generate ideas?

Participants' Responses:
A: No
$B: N o$
$C: Y e s$
D: Yes
E: No

Question: What do you think about clustering technique? Does it help you to generate more ideas for writing?

\section{Participants' Responses:}
A: Yes. Can write more
$B$ : Yes. Can write more
C: Yes. Can help me think what to write
D: Yes. Can help me to write more ideas
E: Yes. Can write more ideas

\section{DISCUSSION AND IMPLICATIONS}

From this research, it was found that clustering technique helps these rural primary pupils to generate more ideas for their writing. By clustering what they wanted to put in their writing activity, they were able to remember details, expand and connect ideas for their composition. One of the limitations occurred in this study was the participants' lack of vocabulary. Most of the time these participants had the ideas of what information they wanted to write on their map but they did not have the vocabulary. One way to overcome this problem is by assisting and guiding them. This can be done by providing the needed vocabulary or asking them to look into the dictionary.

This research is beneficial for other teachers especially those who teach in the rural areas where the pupils are low proficient in English. They could use this technique in teaching writing for pupils who faced difficulties in this skill. Pupils, on the other hand, will be able to use this technique to generate ideas for their writing. It provides a platform for them to write details or information in order to construct and elaborate more on their composition. Other than that, future researchers could explore this knowledge and use it to conduct research in other places.

\section{CONCLUSION}

As a conclusion, clustering technique could act as an alternative for writing especially during the pre-writing session as it allows pupils to explore ideas for their writing. This technique is easy and suitable to conduct for schools with limited access of amenities.

\section{REFERENCES}

[1] Ahangari, S., \& Behzady, L. 2011. The Effect of Explicit Teaching of Concept Maps on Iranian EFL.
[2] Alawi. F.F. 2011. Improving students' ability in writing descriptive text using clustering technique. Jakarta: English Education Department, Faculty of Tarbiyah and Teachers' Training, Syarif Hidayatullah State Islamic University.

[3] Barkaoui, K. 2007. Teaching writing to second language learners Insights from theory and research. TESL Reporter, 40(1), 35-48.

[4] Buscemi, S.V. 2002. A Reader for Developing Writers. New York: McGraw-Hill Companies, Inc. 14

[5] Chitravelu, N., Sithamparam, S. \& Teh S, C. 2005. ELT Methodology: Principles and practice. Shah Alam: Penerbit Fajar Bakti Sdn.Bhd.

[6] Cunningham., P., M. \& Cunningham., J., M. 2010. What really matter in writing. United States of America : Pearson.

[7] Fatt, C.W. 2007. The effects of time constraints and proficiency on ESL essay writing performance. Unpublished $\mathrm{PhD}$ thesis, Universiti Sains Malaysia.

[8] Firmansyah, A. 2015. The Influence of Mind Mapping Technique and Students' Attitude toward Students' Ability in Writing a Recount Text of the Eighth Grade Students of State Junior High School 45 Palembang. RIPTEKSI KEPENDIDIKAN PGRI.

[9] Flower, L., \& Hayes, J. 1977. Problem-solving strategies and the writing process. Carbondale: Southern Illinois University Press.

[10] Folit, R. 2009. Gabriele Lusser Rico Talks about the Benefits of Journaling. Retrieved from: https://www.lifejournal.com/gabriele-lusser-rico-talks-about-the-benef its-of-journaling/

[11] Kemmis, S., \& McTaggart, R. 1988. The action research planner (3rd ed). Victoria: Deakin University.

[12] Langan, J. 2005. College writing skills. New York: McGraw-Hill Companies Inc. 27

[13] McNiff, J. 2002 Action Research: Principles and Practice. London: Routledge.

[14] Nik, Y. A., Hamzah, A., \& Rafidee, H. 2010. A comparative study on the factors affecting the writing performance among Bachelor students. International Journal of Educational Research and Technology, 1(1), 54-59.

[15] Nooreiny. M. et al. 2003. Keupayaan penguasaan kemahiran bahsa inggeris di kalangan pelajar Melayu dalam arus globalisasi. Dlm. Prosiding Seminar Kebangsaan Arus Perdana 11, 226-266. Bangi: Universiti Kebangsaan Malaysia.

[16] Palincsar, A. S. 1998. Keeping the metaphor of scaffolding fresh: A response to C. Addison Stone's 'The metaphor of scaffolding.' Journal of Learning Disabilities, 31(4), 370-373.

[17] Polisena, J. 2017. Importance of Writing in Elementary Schools Synonym. Retrieved from https://classroom.synonym.com/importance-writing-elementary-school s-8215.html

[18] Richards, J.C., \& Renandya, W.A. 2002. Methodology in Language Teaching (An Anthology of Current Practice). Cambridge: Cambridge University Press.

[19] Saed, H. A., \& AL-Omari, H. A. 2014. The Effectiveness of a Proposed Program Based on a Mind Mapping Strategy in Developing the Writing Achievement of Eleventh Grade EFL Students in Jordan and Their Attitudes Towards Writing. Journal of Education and Practice, 5 , 88-109.

[20] Samuel, R., \& Bakar, Z. 2008. The effectiveness of 'VELT' in promoting English language communication skills: A case study in Malaysia. International Journal of Education and Development using ICT, 4(3), 1-14. $\quad$ Retrieved from http://ijedict.dec.uwi.edu/viewarticle.php?id=559\&layout=html

[21] Smalley, R., L., Ruetten. M., K. 2012. Refining composition skill (4 $^{\text {th }}$ ed). New York: Longman Pearson Education Inc. 10

[22] Talif, R., \& Edwin, M. (1990). A comparative study of the achievement and the proficiency levels in English as a second language among learners in selected rural and urban schools in peninsular Malaysia. The English Teacher, 19

[23] Wyrick, J. 2011. Steps to writing well and additional readings $\left(8^{\text {th }} \mathrm{ed}\right)$. New York: Wadsworth.

Sharon Lawai currently works as a teacher in one of the rural primary school in Malaysia.

Azlina Abdul Aziz is a lecturer at Faculty of Education, National University of Malaysia. 